\title{
SEBARAN DAN KELIMPAHAN IKAN KARANG DI PERAIRAN PULAU LIUKANGLOE, KABUPATEN BULUKUMBA
}

\section{DISTRIBUTION AND ABUNDANCE OF CORAL FISH IN LIUKANGLOE ISLAND WATER, BULUKUMBA DISTRICT}

\author{
Chair Rani*, Abdul Haris, Inayah Yasir dan Ahmad Faizal \\ Departemen Ilmu Kelautan, Fakultas Ilmu Kelautan dan Perikanan, \\ Universitas Hasanuddin, Makassar, 90245, Indonesia \\ *E-mail: erickch_rani@yahoo.com
}

\begin{abstract}
Coral fish are fish that are associated with coral reefs and their existence is determined by the variety and complexity of coral reefs. The purpose of this study was to analyze the dynamics of species richness and abundance of reef fish in several locations on the coral reefs of Liukangloe Island, Bulukumba District and their relation to live and dead coral cover. The research method was used LIT to know life and dead coral cover and Visual Census to record of reef fish. The data was done at 6 stations and each at 2 depths $(3-5 \mathrm{~m}$ and $8-10 \mathrm{~m})$ with 3 repetitions of transects (area: $80 \mathrm{~m}^{2}$ ). The species number and abundance of fish between stations were analyzed by ANOVA, while between depth was analyzed by $t$-student. The relationship between fish species richness and abundance and life and dead coral cover was done by regression and corelation analysis. The species number at a depth of 3-5 $\mathrm{m}$ according to the observation periode was very dynamic and showed significant differences between stations, while at depths of 8-10 meters, relatively stable and no different between stations. The abundance of fish at a depth of 8-10 meters was higher at 3-10 meters. Stations with high live coral cover was showed a higher species number of reef fish and was significantly different from stations with low live coral cover, but not in terms of abundance. Although positively correlated, the relationship between live coral cover and the number and abundance of reef fish were relatively weak. Conversely, negatively correlated with high dead coral cover.
\end{abstract}

Keywords: abundance, coral bleaching, distribution, Liukangloe Island, reef fishes

\section{ABSTRAK}

Ikan karang merupakan ikan yang berasosiasi dengan terumbu karang dan keberadaannya ditentukan oleh variasi dan kompleksitas terumbu karang. Penelitian ini bertujuan untuk menganalisis dinamika kekayaan jenis dan kelimpahan ikan karang pada beberapa lokasi di terumbu karang Pulau Loukangloe, Kabupaten Bulukumba dan keterkaitannya dengan tutupan karang hidup dan karang mati. Metode LIT digunakan untuk mengetahui tutupan karang hidup dan karang mati dan teknik visual sensus untuk mendata struktur komunitas ikan karang. Pendataan dilakukan pada 6 stasiun dengan 2 kedalaman (3-5 m dan 8-10 m) dan 3 kali pengulangan transek (luas area pemantauan $80 \mathrm{~m}^{2}$ ). Perbandingan kekayaan jenis dan kelimpahan ikan karang antar stasiun diuji dengan analisis ragam, sedangkan antar kedalaman dianalisis dengan uji t-student. Hubungan antar kekayaan jenis dan kelimpahan ikan dengan kondisi terumbu karang dilakukan dengan analisis regresi dan korelasi. Jumlah jenis pada kedalaman 3-5 m sangat dinamis di setiap bulan pengamatan dan memberikan perbedaan yang nyata, sedangkan di kedalaman 8-10 m, relatif stabil dan tidak berbeda antar stasiun. Kelimpahan ikan karang pada kedalaman 8-10 m lebih tinggi dan berbeda nyata dari kedalaman 3-10 $\mathrm{m}$. Tutupan karang hidup yang tinggi memperlihatkan jumlah jenis ikan karang yang lebih kaya dan berbeda nyata dengan stasiun yang tutupan karang hidupnya rendah, namun tidak dalam hal kelimpahannya. Meskipun berkorelasi positif, namun hubungan antara tutupan karang hidup dengan jumlah jenis dan kelimpahan ikan karang tergolong lemah. Sebaliknya, berkorelasi negatif dengan tutupan karang mati yang tinggi.

Kata kunci: distribusi, ikan karang, kelimpahan, Pulau Liukangloe, struktur komunitas 


\section{PENDAHULUAN}

Ikan karang merupakan salah satu kelompok hewan yang berasosiasi dengan terumbu karang. Keberadaannya nyata dan ditemukan pada berbagai mikro-habitat di terumbu karang. Variasi habitat terumbu karang, dalam hal ini variasi mikro-habitat tidak hanya terdiri dari habitat karang saja, tetapi juga daerah berpasir, berbagai teluk dan celah, daerah alga dan sponge serta masih banyak lagi. Keberagaman habitat tersebut merupakan salah satu faktor kunci tingginya keragaman spesies ikan di terumbu karang sehingga habitat yang beranekaragam ini dapat menerangkan jumlah ikan-ikan karang pada ekosistem tersebut (Luckhurst and Luckhurst, 1978; Robert and Ormond, 1987).

Kompleksitas ruang di terumbu karang menawarkan tempat berlindung bagi berbagai ragam fauna (Connell, 1978). Dari beberapa hasil studi menyebutkan bahwa kompleksitas fisik/substrat terumbu karang berkorelasi positif dengan keragaman ikan, tetapi tidak dengan kelimpahannya (Luckhurst and Luckhurst, 1978; Talbot et al., 1978; Roberts and Ormond, 1987). Secara biologis, sifat substrat yaitu kekayaan spesies karang dan/atau karang hidup, tidak memiliki pengaruh terhadap keanekaragaman dan kelimpahan ikan (Luckhurst and Luckhurst 1978; McManus et al., 1981; Roberts and Ormond 1987; BouchonNavaroa et al., 2005), namun penelitian lain, karakteristik ikan berkorelasi positif dengan karang hidup (Carpenter et al., 1981; Sano et al., 1984; Bell and Galzin, 1984).

Gangguan yang terjadi pada terumbu karang akan menyebabkan penurunan kelimpahan ikan karang. Beberapa dampak hilangnya karang pada ikan akan terlihat dalam jangka waktu yang relatif singkat (minggu/ bulan), seperti menurunnya kondisi fisiologis dan aktivitas reproduksi suatu komunitas ikan (Pratchett et al., 2004). Dalam jangka waktu yang lebih lama (tahunan) dapat menyebabkan kelimpahan dan keanekaragaman ikan yang lebih rendah (Wilson et al., 2006).

Ikan karang menetap serta mencari makan di areal terumbu karang (sedentary), jika terumbu karang rusak atau hancur maka ikan karang juga akan kehilangan habitatnya. Sebagai ikan yang hidupnya terkait dengan terumbu karang maka kerusakan atau penurunan kondisi terumbu karang dengan sendirinya berpengaruh terhadap keragaman dan kelimpahan ikan karang. Kejadian coral bleaching pada bulan Mei 2016 di terumbu karang Pulau Liukangloe menyebabkan tutupan karang sekitar $13,12 \%$ pada kedalaman 10 m dan kurang lebih 6-7\% pada kedalaman $3 \mathrm{~m}$ (Nirwan et al., 2017), sehingga terjadi kematian karang dan mengubah struktur dasar terumbu karang. Perubahan tersebut akan berdampak ke biota yang berasosiasi, termasuk ikan karang. Berdasarkan kondisi tersebut maka penelitian ini dilakukan dengan tujuan menganalisis dinamika kekayaan jenis dan kelimpahan ikan karang pada beberapa lokasi di terumbu karang Pulau Liukangloe dan menganalisis keterkaitan antara tutupan karang hidup dan karang mati dengan struktur komunitas ikan karang.

\section{METODE PENELITIAN}

\subsection{Waktu danTempat}

Penelitian ini berlangsung selama 4 (empat) bulan mulai dari bulan Juli-Oktober 2017 di terumbu karang Pulau Liukangloe, Kabupaten Bulukumba (Gambar 1). 


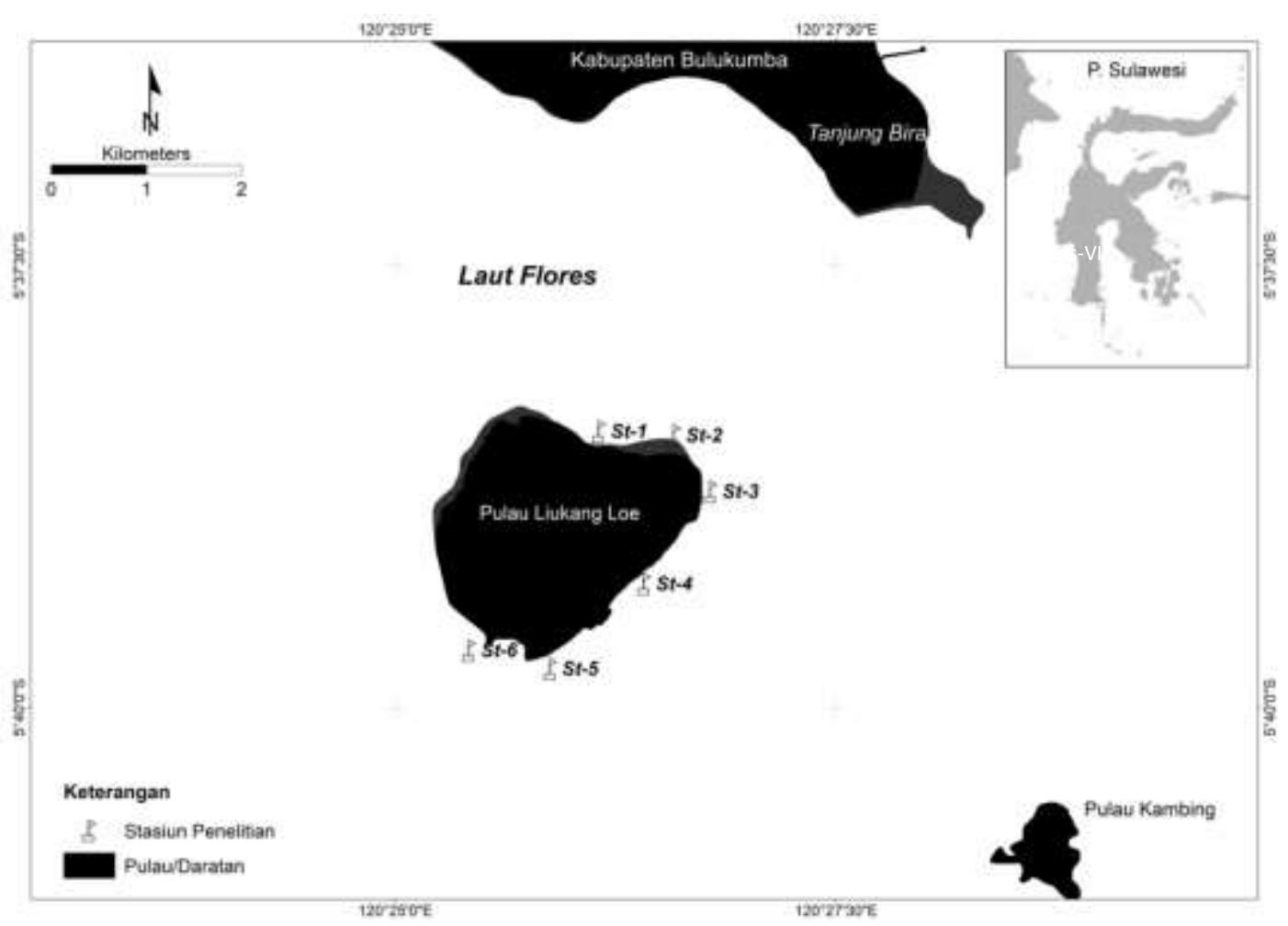

Gambar 1. Peta lokasi penelitian di terumbu karang Pulau Liukangloe, Kab. Bulukumba.

\subsection{Prosedur Penelitian}

\subsubsection{Penentuan Stasiun Penelitian}

Lokasi penelitian ditentukan dengan melakukan snorkeling terlebih dahulu untuk mengetahui kondisi secara umum, kemudian dilanjutkan dengan penetapan posisi stasiun pengamatan dengan menggunakan GPS (Global Positioning System). Titik lokasi penelitian terdiri dari 6 stasiun. Stasiunstasiun tersebut menyebar dari utara sampai ke selatan pulau mengikuti pola sebaran karang di lokasi penelitian (Gambar 1).

\subsubsection{Pengambilan Data}

\subsubsection{Pengambilan Data Tutupan}

Karang Hidup dan Karang Mati

Pengambilan data tutupan karang hidup dan karang mati dilakukan dengan teknik Lifeform Intercept Transect (LIT). Transek dibentang sejajar garis pantai dengan panjang $70 \mathrm{~m}$. Transek tersebut kemudian dibagi menjadi 3 subtransek masing-masing sepanjang $20 \mathrm{~m}$ dengan 3 kali ulangan dan dipisahkan jarak sejauh 5 m. Penempatan transek garis dilakukan pada
2 kedalaman yaitu antara 3-5 m dan 8-10 m di setiap stasiun. Pendataan tutupan dilakukan dengan mencatat panjang intersep dari setiap lifeform karang yang memotong transek garis dalam satuan $\mathrm{cm}$. Data lifeform tersebut kemudian dikelompokkan dan dipisahkan sesuai dengan target data yang diperlukan, yaitu kelompok karang hidup (life coral: Acropora dan Non-Acropora) ) dan karang mati (dead coral: DC dan dead coral with algae: DCA) dan dihitung persentase tutupannya.

\subsubsection{Kekayaan dan Kelimpahan Jenis Ikan Karang \\ Kelimpahan ikan karang didata} dengan menggunakan metode sensus visual (Visual Census Method) (English et al., 1994) yang secara teknis dilakukan dengan metode transek sabuk (Belt Transect) mengikuti titik dan panjang transek garis dalam pengamatan tutupan karang $(20 \mathrm{~m})$. Pengambilan data ikan dan karang dilakukan secara berurutan. Setelah pendataan ikan selesai, selang beberapa menit diikuti 
dengan pendataan karang. Kegiatan pendataan ikan karang dimulai beberapa menit setelah pemasangan transek. Kelimpahan ikan tiap jenis mulai dihitung dengan batasan jarak pantau 2,5 m pada sisi kiri dan kanan transek (English et al., 1994). Identifikasi jenis ikan karang dilakukan secara langsung di lapangan (Allen, 2000; Kuiter dan Tonozuk, 2001).

\subsection{Analisis Data}

Menghitung persentase (\%) tutupan karang hidup dan karang mati menggunakan formula menurut English et al. (1994) sebagai berikut:

$$
\begin{aligned}
& \text { Penutupan Setiap_Kategori }(\%)= \\
& \frac{\text { Panjang-penutupan-setiap Kategori Karang }}{\text { Total panjang_transek_(2000cm })} \times 100
\end{aligned}
$$

Data tutupan dasar terumbu karang dikelompokkan menurut stasiun dan kedalaman serta disajikan dalam bentuk grafik histogram untuk dianalisis secara deskriptif. Komposisi jenis ikan karang dihitung dengan formula: $\mathrm{KJ}=\mathrm{ni} / \mathrm{Nx} 100$; dengan $\mathrm{KJ}=$ komposisi jenis $(\%)$; ni =jumlah individu setiap jenis ikan; dan $\mathrm{N}=$ jumlah individu dari seluruh jenis ikan. Komposisi jenis ikan karang dikelompokkan dengan penggolongan ikan karang (mayor, indikator, dan target). Data tersebut selanjutnya dianalisis secara deskriptif dengan bantuan diagram.

Jumlah jenis dan kelimpahan ikan karang dikelompokkan menurut kedalaman, stasiun dan waktu pengamatan. Kelimpahan total ikan karang dinyatakan dalam satuan jumlah ekor perluasan transek $\left(100 \mathrm{~m}^{2}\right)$. Jumlah jenis dan kelimpahan ikan karang dianalisis dengan analisis ragam (one way anova). Hasil analisis disajikan dalam bentuk grafik. Proses pengolahan datanya dilakukan dengan bantuan perangkat lunak SPSS.

\section{HASIL DAN PEMBAHASAN}

\subsection{Struktur Komunitas Ikan Karang}

Selama penelitian, tercatat kekayaan jenis ikan karang berkisar 199-222 jenis pada semua stasiun. Jumlah jenis ikan terendah ditemukan pada awal penelitian (Juli 2017), kemudian meningkat dan tertinggi di akhir penelitian (Oktober 2017). Sebanyak 222 jenis ikan karang terdata di bulan Oktober 2017 yaitu berasal dari 34 familia dan 88 genera. Famili Chaetodontidae (ikan indikator), Labridae, Pomacentridae, Acanthuridae, dan Scaridae merupakan famili yang mendominasi jenis ikan karang di lokasi penelitian. Jenis ikan indicator (Chaetodontodae) tercatat sebanyak 24 jenis, secara langsung menunjukkan kondisi terumbu karang di lokasi penelitian masih dalam kondisi yang bagus untuk kehidupan ikan karang. Kekayaan jenis ikan herbivora yaitu dari famili Scaridae dan Acanthuridae membantu dalam perkembangan atau pemulihan kondisi terumbu karang akibat fenomena bleaching. Diketahui bahwa ikanikan herbivora membantu membersihkan substrat karang mati atau karang hancur dari alga filamen (makroalga) ketika melakukan grazing (makan) sehingga membuka ruang untuk pelekatan planula karang dalam proses rekrutmen.

Ikan karang berdasarkan fungsinya dibedakan menjadi 3 golongan masingmasing; ikan target (ikan ekonomis yang menjadi target nelayan), ikan indikator (indikator kesehatan terumbu karang), dan ikan mayor (umum diterumbu karang dan berperan dalam menjaga keseimbangan ekosistem dan aliran energi). Berdasarkan penggolongan tersebut, secara umum ikan karang di perairan terumbu karang di sekitar Pulau Liukangloe tersaji pada Gambar 2. Komposisi jenis ikan berdasarkan hasil pengamatan Juli-Oktober 2017 didominasi oleh ikan mayor $(55,94-61,26 \%)$, selanjutnya ikan target $(27,93-31,68 \%)$, 
dan ikan indikator sebesar 10,81-12,58\%. Demikian pula jumlah individu (komposisi individu) didominasi oleh ikan mayor $(61,97$ $81,28 \%)$, ikan target $(16,29-35,47 \%)$ dan ikan indikator (1,94-2,94\%).

Komposisi ikan karang baik berdasarkan jenis maupun jumlah individu menunjukkan bahwa ikan mayor mendominasi keberadaan ikan karang di Pulau Liukangloe (Gambar 2). Dari 6 stasiun pengamatan memperlihatkan variasi bulanan tidak terlalu berpengaruh terhadap jumlah jenis maupun jumlah individu ikan mayor. Tingginya kelimpahan ikan mayor sangat beralasan karena jenis ikan ini bukan menjadi target penangkapan dari nelayan, pada umummya ikan jenis ini adalah ikan hias yang ada pada terumbu karang (Hukom dan Syahailatua, 2010). Hal yang sama juga ditemukan di terumbu karang di Minasaha Utara, baik terumbu karang yang berada di daerah perlindungan maupun di luar daerah perlindungan laut (Setiawan et al., 2016). Jumlah individu ikan mayor merupakan kelompok ikan karang yang memiliki kelimpahan yang tertinggi. Selanjutnya dikatakan, tingginya kelimpahan ikan mayor tersebut merupakan sesuatu yang umum karena pada daerah terumbu karang, kelompok ini memang sangat dominan dijumpai baik dalam hal jumlah jenis maupun kelimpahannya.
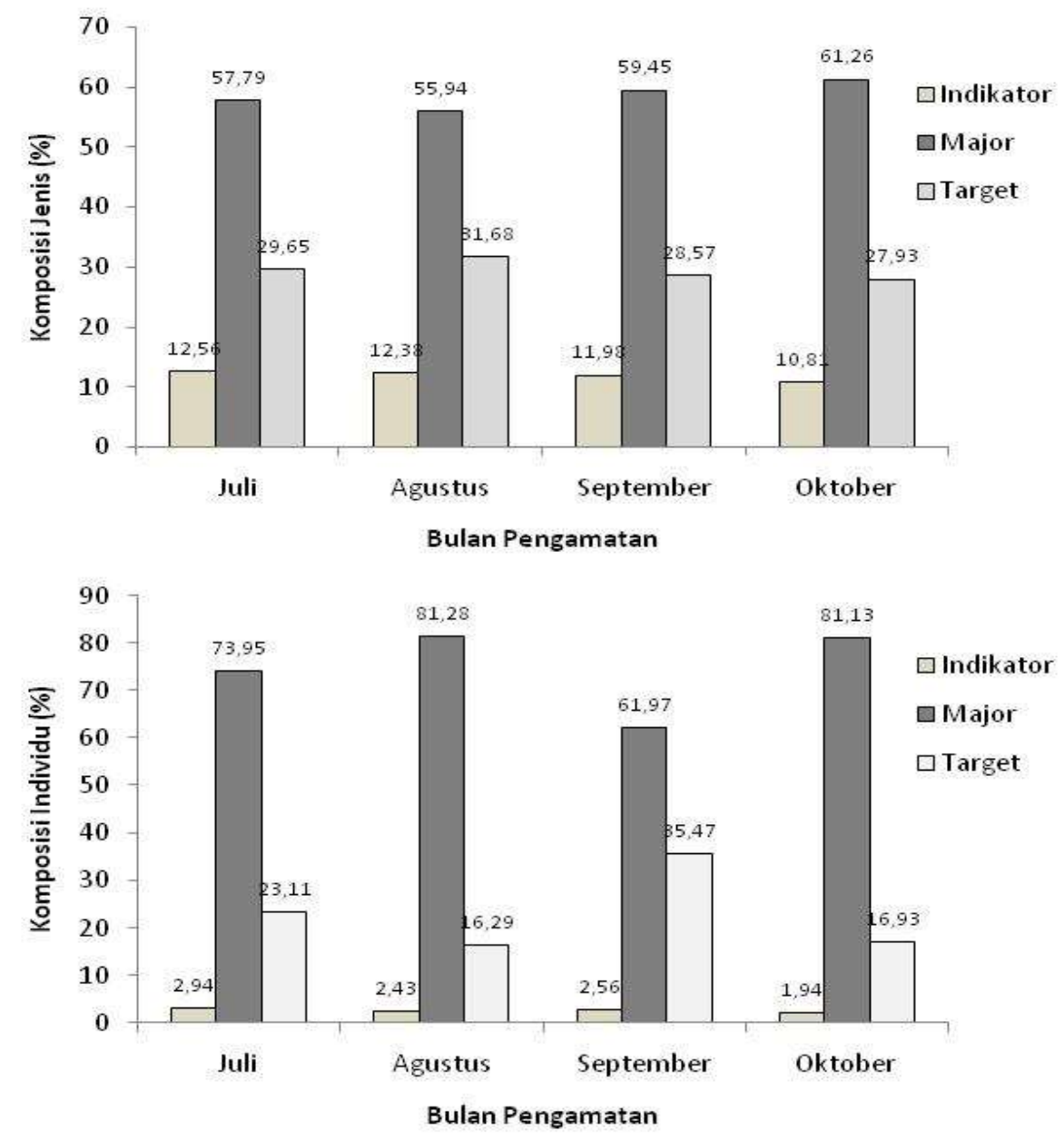

Gambar 2. Komposisi ikan karang menurut jumlah jenis (atas) dan jumlah individu (bawah) berdasarkan bulan pengamatan di terumbu karang Pulau Liukangloe, Kab. Bulukumba. 
Ikan target yang merupakan ikan-ikan yang bernilai ekonomis dan merupakan target tangkapan nelayan. Kelimpahan ikan target yang tinggi menjadi salah satu indikator untuk melihat seberapa besar tingkat eksploitasi ikan di daerah terumbu karang. Berdasarkan komposisi jenis, ikan target paling banyak ditemukan pada bulan Agustus (31,68 \%) dan paling rendah bulan Oktober (27,93\%), sedangkan berdasarkan jumlah individu paling tinggi ditemukan pada bulan September 35,47 \%. Jenis ikan target yang paling banyak ditemukan adalah famili Scaridae. Hal ini juga sesuai dengan kondisi terumbu karang yang dominan dari Coralline Algae.

Umummnya jumlah jenis ikan indikator pada setiap bulan pengamatan cenderung sama, dengan jumlah tertinggi pada bulan Juli (12,56 \%) sedangkan jumlah individu paling tinggi ditemukan pada bulan Juli $(2,94 \%)$. Fenomena ini mengindikasikan bahwa semakin baik kondisi terumbu karang maka jumlah jenis dari ikan indikator juga akan semakin besar. Beberapa studi menunjukkan bahwa penutupan karang hidup memiliki pengaruh yang positif terhadap kekayaan jenis ikan karang (Carpenter et al., 1981; Ghiffar et al., 2017).

\subsection{Kekayaaan dan Kelimpahan Ikan Karang}

Ikan karang adalah fauna laut yang kekayaan jenisnya sangat dipengaruhi oleh kondisi habitat seperti naungan, substrat, faktor fisika kimia air dan makanan. Pada kondisi hamparan karang yang luas dengan keanekaragaman karang yang relatif tinggi serta kondisi karang hidup yang tinggi merupakan penciri dari lokasi yang banyak terdapat ikan (Allen, 2000).

Hasil pemantauan ikan karang pada periode Juli-Oktober 2017, pada dua kedalaman (3-5 m) dan (8-10 m) (Gambar 3), menunjukkan bahwa ada kecenderungan terjadinya peningkatan jumlah jenis ikan karang khususnya pada Stasiun IV, V, dan
VI, kecuali Stasiun Stasiun II dan III yang relatif konstan.
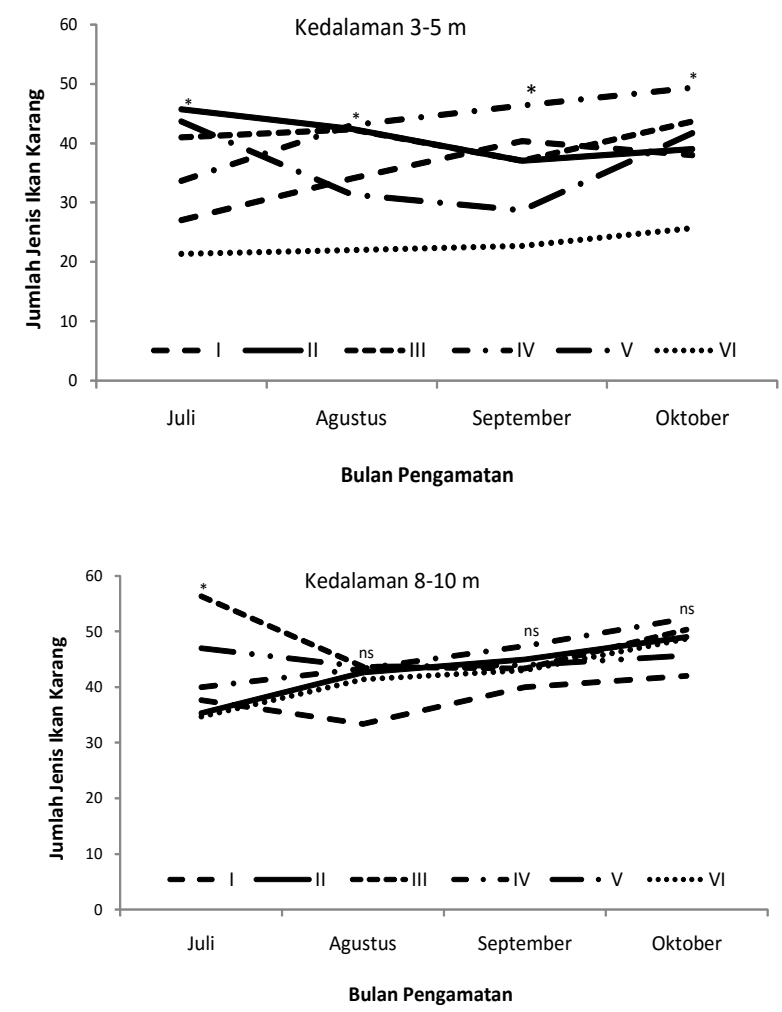

Gambar 3. Jumlah jenis ikan karang pada setiap stasiun berdasarkan waktu pengamatan di kedalaman 3-5 m (atas) dan di kedalaman 8-10 m (bawah) di terumbu karang Pulau Liukangloe, Kab. Bulukumba. Simbol (*) menunjukkan perbedaan yang nyata dan simbol $\left({ }^{\text {ns }}\right)$ menunjukkan tidak adanya perbedaan yang nyata antar stasiun pada alpha $5 \%$ berdasarkan analisis ragam.

Gambar 3 menunjukkan bahwa pada kedalaman 3-5 m kekayaan jenis ikan karang untuk setiap stasiun menunjukkan perbedaan antar stasiun penelitian $(\mathrm{P}<0,05)$ pada setiap periode sampling. Sedangkan pada kedalaman 8-10 m terlihat bahwa hanya pada bulan Juli terdapat perbedaan yang nyata antar stasiun pengamatan $(\mathrm{p}<0,05)$, tetapi pada bulan Agustus-Oktober tidak memperlihatkan perbedaan secara nyata pada 
jumlah jenis ikan antar stasiun. Stasiun dengan kondisi terumbu karang yang rusak seperti pada Stasiun VI memiliki kekayaan jenis ikan karang yang lebih rendah dibandingkan dengan Stasiun II, III, IV dan $\mathrm{V}$ yang masih memiliki kondisi terumbu karang yang masih baik. Menurut Rani et al. (2011), kondisi terumbu karang dalam hal ini dicerminkan melalui penutupan karang hidupnya berhubungan secara nyata dengan kelimpahan ikan namun tidak nyata hubungannya dengan kekayaan jenis ikan. Tidak nyatanya hubungan antara tutupan karang hidup dengan kekayaan jenis ikan karang disebabkan karena, pada beberapa lokasi di wilayah pesisir memiliki keragaman ekosistem sehingga berpengaruh terhadap kekayaan jenis ikan.

Lebih jauh tentang kondisi jumlah jenis ikan karang berdasarkan kedalaman pada setiap stasiun menurut bulan pengamatan disajikan pada Gambar 4.
Gambar tersebut menunjukkan bahwa secara umum hampir semua stasiun tidak menunjukkan perbedaan jumlah jenis ikan antar kedalaman di setiap bulannya. Berdasarkan bulan, pada bulan Juli, Agustus dan Oktober hanya Stasiun VI yang memiliki jumlah jenis ikan yang berbeda pada kedalaman 3-5 m dan 8-10 m ( $\mathrm{p}<0,05)$, sedangkan stasiun pengamatan lainnya tidak memperlihatkan perbedaan yang nyata antar kedalaman. Lain halnya pada bulan September, Stasiun II dan VI menunjukkan adanya perbedaan jumlah jenis ikan pada kedalaman 3-5 m dengan 8-10 m, sedangkan stasiun lainnya tidak menunjukkan perbedaan yang siginifikan. Jika dilihat persebaran stasiun pada keseluruhan waktu pengamatan (Juli-Oktober) maka Stasiun I, III, IV dan V tidak menunjukkan perbedaan jumlah jenis ikan, sedangkan pada Stasiun II dan VI menunjukkan perbedaan.
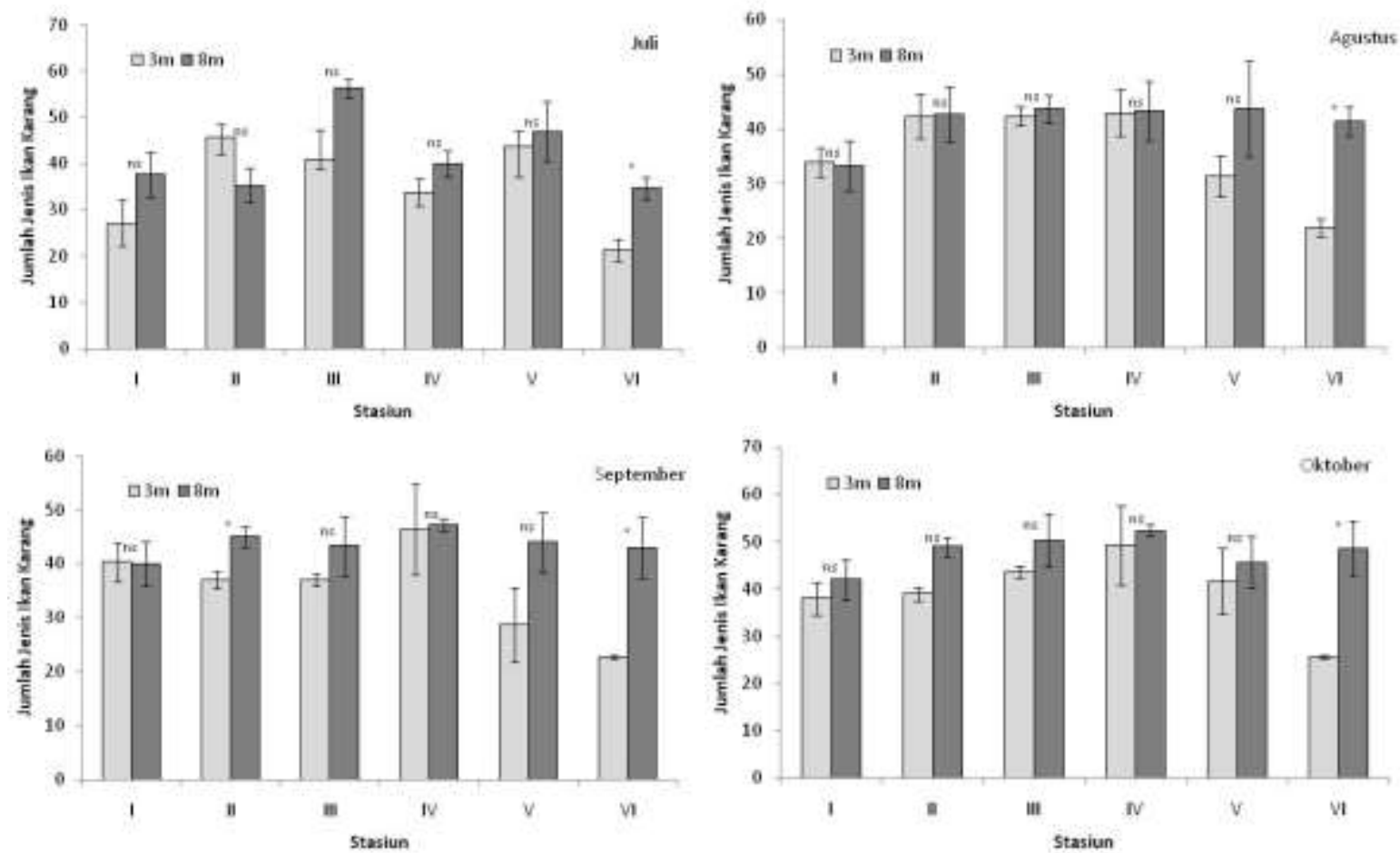

Gambar 4. Perbandingan jumlah jenis ikan karang antar kedalaman di setiap stasiun menurut bulan pengamatan di terumbu karang Pulau Lukangloe, Kab. Bulukumba. Simbol $\left({ }^{\mathrm{ns}}\right)$ menunjukkan tidak adanya perbedaan yang nyata dan simbol $(*)$ menunjukkan perbedaan yang nyata antar stasiun penelitian pada alpha $5 \%$, berdasarkan uji $t$ student. 
Rata-rata jumlah jenis ikan karang di setiap stasiun tidak menunjukkan perbedaan antara kedalaman 3-5 m dan 8-10 m pada setiap periode sampling. Fenomena ini menggambarkan bahwa kondisi lingkungan terumbu karang yang menentukan kekayaan jenis ikan karang relatif sama, seperti kehadiran padang lamun di sekitar terumbu karang pada setiap stasiun dan tingkat rugositasnya, termasuk tingkat eksploitasi juga yang cenderung sama. Pengecualian pada Stasiun VI, keberadaan padang lamun cenderung jauh dan relatif sempit serta kondisi terumbu karang yang relarif rusak, terutama di kedalaman 8-10 m.
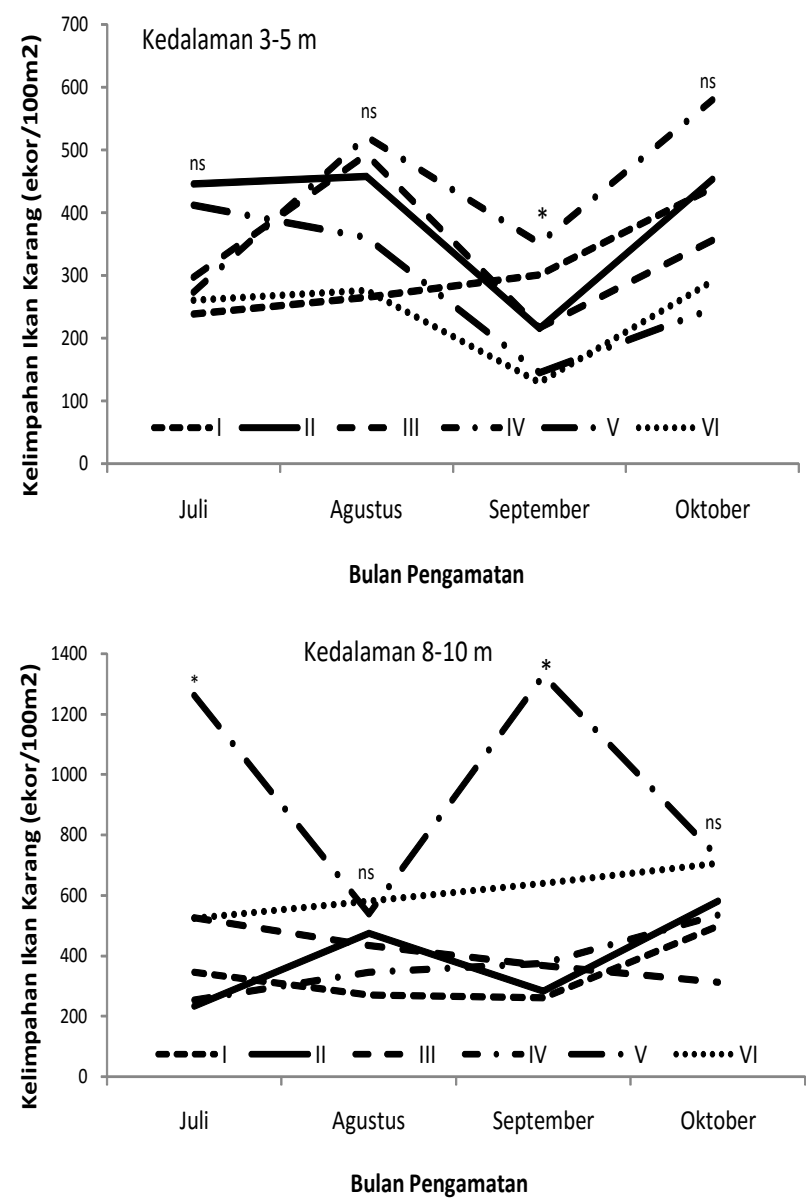

Gambar 5. Kelimpahan jenis ikan karang pada setiap stasiun menurut waktu pengamatan di kedalaman 3-5 m (atas) dan 8-10 m (bawah) di terumbu karang Pulau Liukangloe, Kab. Bulukumba. Simbol (*) menunjukkan per- bedaan yang nyata dan simbol $\left({ }^{n s}\right)$ menunjukkan tidak adanya perbedaan yang nyata antar stasiun pada alpha $5 \%$ berdasarkan analisis ragam.

Sebaran kelimpahan ikan karang di setiap stasiun pada setiap bulan pengamatan, baik pada kedalaman 3-5 m maupun di kedalaman 8-10 m, cenderung tidak berbeda nyata $(\mathrm{P}>0.05)$ antar stasiun (Gambar 5). Kondisi berbeda nyata $(\mathrm{P}<0,05)$ pada kedalaman 3-5 $\mathrm{m}$ hanya terjadi di bulan September dan pada kedalaman 8-10 m terjadi pada bulan Juli dan September. Kelimpahan yang tinggi teramati di Stasiun IV dan V. Salah satu penyebab tingginya kelimpahan ikan di kedua stasiun tersebut, yaitu kehadiran ekosistem lamun yang luas di sekitar stasiun pengamatan. Kompleksitas habitat sangat berpengaruh terhadap kelimpahan suatu organisme. Menurut Gratwicke (2004), keanekaragaman dan variasi bentuk pertumbuhan merupakan predictor yang paling penting untuk kekayaan jenis ikan karang, namun variasi bentuk habitat adalah predictor yang paling berguna untuk kelimpahan ikan karang.

Gambar 6 terlihat bahwa tidak ada perbedaan yang nyata kelimpahan ikan karang $(\mathrm{P}>0,05)$ antara kedalaman 3-5 $\mathrm{m}$ dan 8-10 m pada periode pengamatan, kecuali pada Stasiun VI pada bulan Juli dan Agustus. Gambar tersebut juga menunjukkan dinamika kelimpahan ikan karang yang cukup variatif, misalnya ditemukannya kelimpahan ikan karang yang tinggi pada kedalaman 8-10 m pada bulan Juli, September dan Oktober. Hal ini juga erat kaitanya dengan rugositas, seperti terlihat pada Stasiun $\mathrm{V}$ dengan kondisi terumbu karang yang relatif bagus menyebabkan kelimpahan ikan juga tinggi. Menurut Rani et al. (2011), bahwa keragaman jenis ikan karang sangat terkait dengan keragaman habitat, selain ditentukan oleh kondisi terumbu karang kelimpahan ikan juga ditentukan oleh tingkat rugositas terumbu karang. 

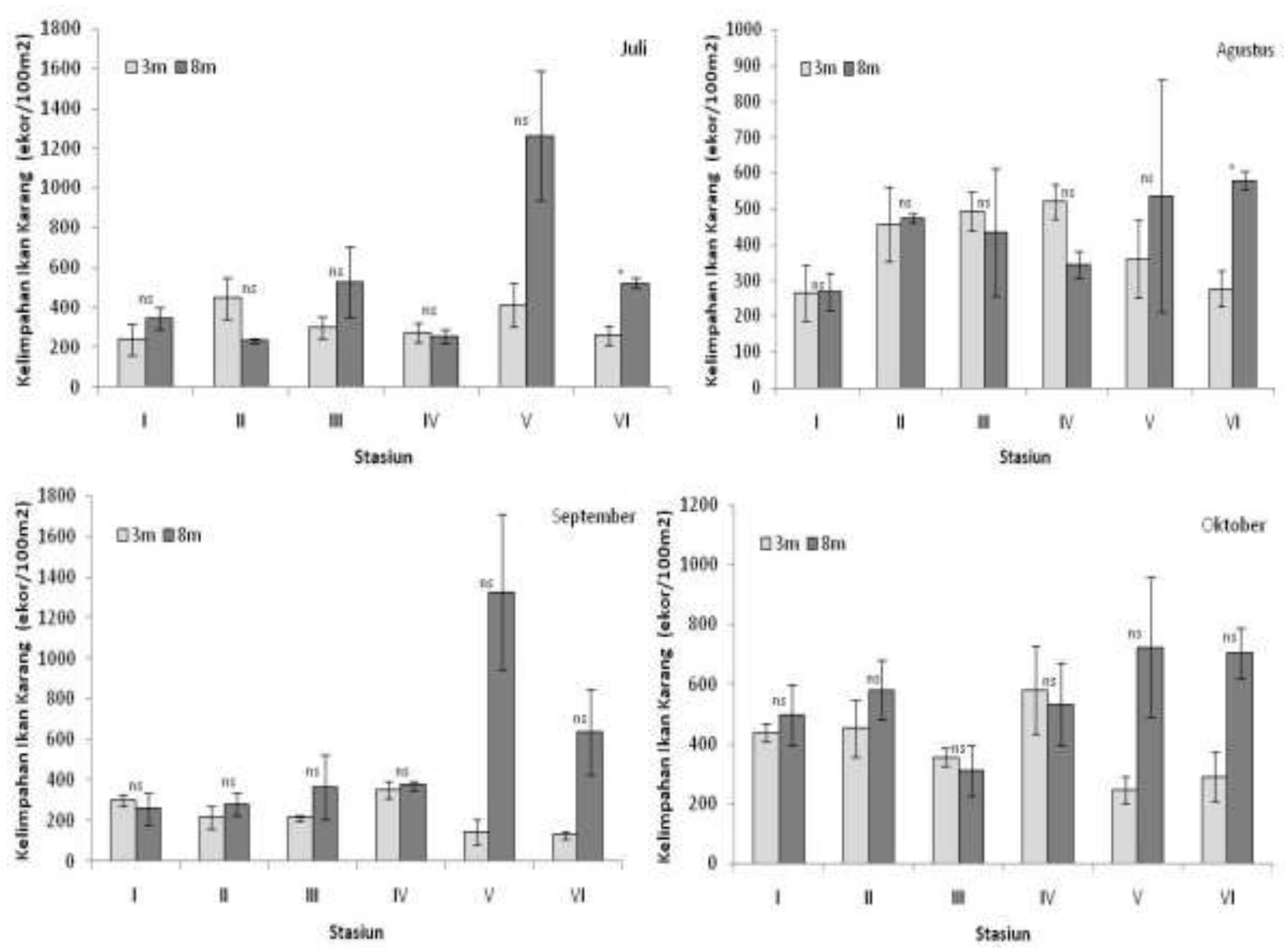

Gambar 6. Perbandingan kelimpahan ikan Karang antar kedalaman di setiap stasiun menurut bulan pengamatan di terumbu karang Pulau Lukangloe, Kab. Bulukumba. Simbol $\left({ }^{\mathrm{ns}}\right)$ menunjukkan tidak adanya perbedaan yang nyata pada alpha $5 \%$, berdasarkan uji $t$-student.

Tingkat rugositas yang tinggi berarti menyediakan lebih banyak tempat persembunyian bagi ikan karang dan menyediakan banyak tempat untuk melekatnya alga, koral, dan berbagai hewan invertebrata. Menurut Luckhurst and Luckhurst (1978), bahwa tingkat rugositas terumbu karang berkaitan erat dengan persentase penutupan dan keanekaragaman karang. Semakin tinggi persentase penutupan dan keanekaragaman karang maka semakin menambah kompleksitas atau kerutan substrat terumbu karang. Sama halnya dengan rugositas, variasi habitat di terumbu karang juga memberikan ruang bagi ikan-ikan karang.

\subsection{Hubungan antara Kondisi Terumbu Karang dengan Struktur Komunitas Ikan Karang \\ Tutupan karang hidup rata-rata pada} kedalaman 3-5 $\mathrm{m}$ berkisar 1,5-63,55 \%, sedangkan pada kedalaman 8-10 m, berkisar 9,58-73,36 \%. Kategori tutupan karang mati (DCA) pada kedalaman 3-5 m, memiliki nilai rata-rata berkisar $0,00-35,16 \%$, sedangkan pada kedalaman 8-10 m berkisar 3,96-52,40 $\%$ (Gambar 7).

Pada dua kedalaman terjadi perbedaan distribusi dari setiap kategori, yaitu di kedalaman 3-5 m lebih didominasi oleh karang hidup, kecuali di Stasiun I (bagian utara pulau), didominasi oleh DCA. Nilai tutupan DCA, tertinggi ditemukan di Stasiun I, sedangkan pada Stasiun II dan III tidak 
ditemukan kehadiran DCA di bawah garis transek. Pada kedalaman 8-10 m didominasi oleh unsur abiotik (pasir) dan DCA, kecuali di Stasiun V, didominasi oleh karang hidup. Distribusi terumbu karang secara vertikal hanya terbatas sampai kedalaman 5-7 m, di bawah kedalaman tersebut distribusi karang umumnya berupa spot-spot dan lebih didominasi oleh hamparan pasir.
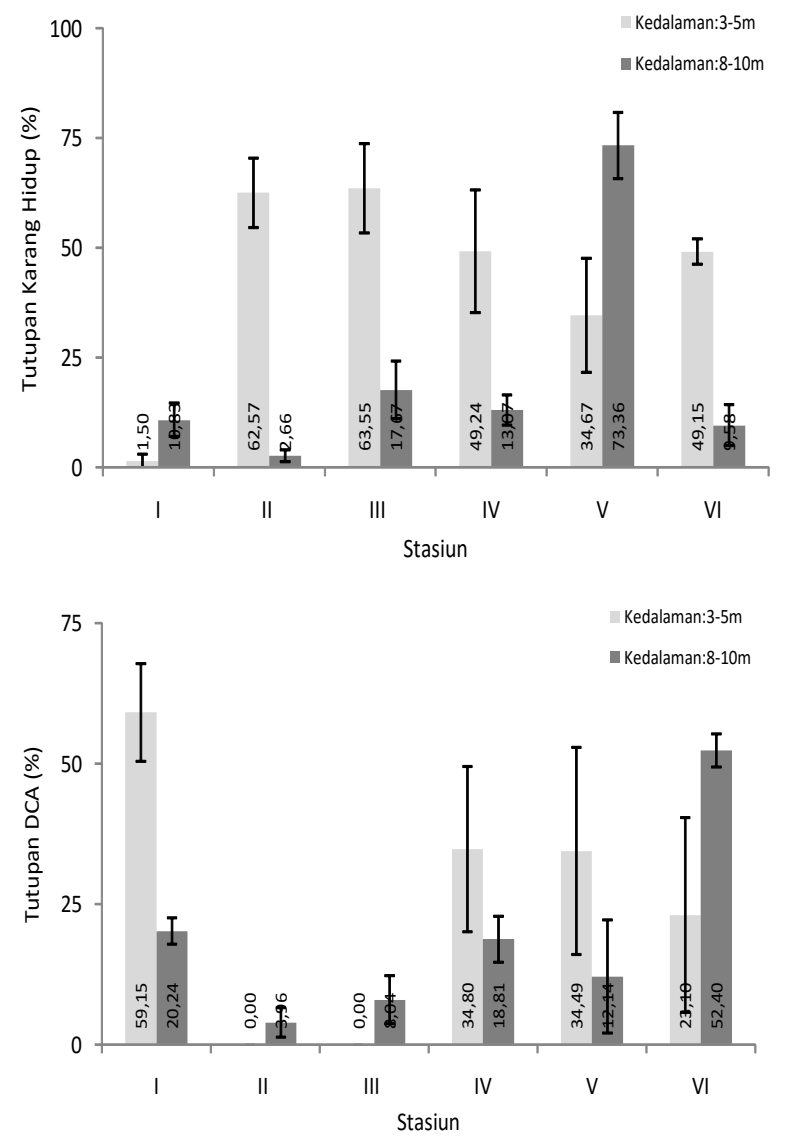

Gambar 7. Nilai tutupan karang hidup (atas) dan karang mati yang sudah ditumbuhi alga: DCA (bawah) pada setiap stasiun di kedalaman 3-5 m dan kedalaman 8-10 m di terumbu karang Pulau Liukangloe, Kab. Bulukumba.

Perubahan kondisi terumbu karang baik oleh peristiwa alam maupun oleh aktivitas antropogenik dapat menyebakan perubahan dalam hal struktur fisik yang mengarah pada perubahan struktur ekologi dari biota asosiasi seperti penurunan atau perubahan komposisi jenis biota asosiasi, termasuk ikan. Pada lokasi penelitian, tutupan karang hidup dan karang mati bervariasi antar titik pengamatan (36 titik pengamatan), demikian pula struktur komunitas ikan menurut waktu sampling (Juli-Oktober).

Hasil analisis ragam menunjukkan bahwa kekayaan jenis ikan karang ditentukan oleh nilai tutupan karang hidup, tetapi tidak dalam hal kelimpahannya. Terlihat bahwa antar kelompok tutupan karang yang lebih tinggi, memiliki jumlah jenis ikan karang yang lebih banyak dan berbeda nyata dengan kelompok dengan tutupan karang hidup yang rendah. Terumbu karang yang masih bagus akan memberikan perlindungan yang lebih baik bagi banyak biota, tempat reproduksi dan pembesaran yang aman bagi anakanaknya. Pada terumbu karang sehat, kuantitas makanannya cukup tinggi, sehingga berdampak secara langsung dan positif bagi keragaman ikan (Robertson dan Gaines, 1986). Terumbu karang menyediakan lingkungan yang tepat untuk kegiatan reproduksi dan penempatan larva ikan sehingga akan turut menentukan struktur komunitas ikan dewasa nantinya (Medley et al., 1983; Lewis, 1987). Terumbu karang yang memiliki struktur kompleks dan sehat akan memaksimalkan jumlah keragaman dan kuantitas ruang dalam proses reproduksi.

Pada kondisi tutupan karang yang rendah $(<50 \%)$ dengan komponen tutupan dasar berupa karang mati yang sudah ditumbuhi alga (DCA), seperti pada beberapa titik di Stasiun VI dan Stasiun I memiliki jumlah ikan yang melimpah meskipun jumlah jenis ikan karangnya lebih sedikit. Ikan-ikan tersebut umumnya sebagai ikan herbivora dari famili Pomacentridae dan Scaridae yang berukuran kecil dan hidup bergerombol.

Keterkaitan antara struktur komunitas ikan karang (jumlah jenis dan kemelimpahan) dan tutupan karang hidup dan karang mati melalui analisis regresi dan korelasi disajikan pada Gambar 8. 

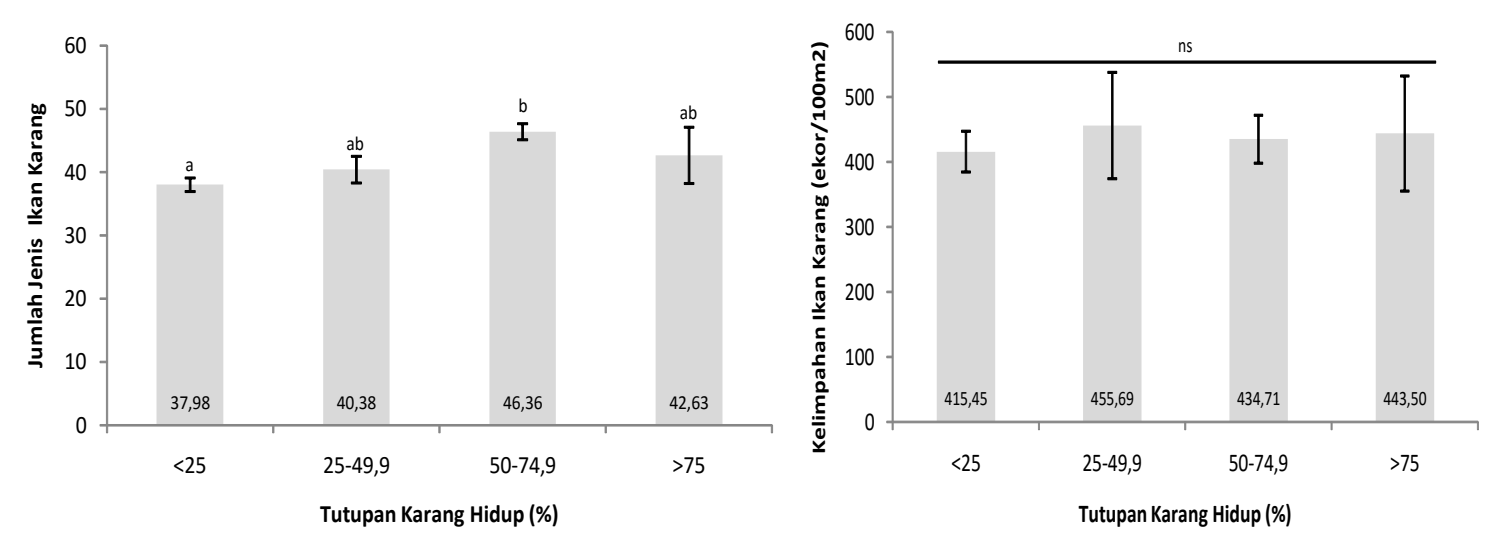

Gambar 8. Sebaran jumlah jenis (atas) dan kelimpahan (bawah) dari ikan karang menurut tutupan karang hidup di perairan Pulau Liukang-loe, Kabupaten Bulukumba. Huruf yang berbeda di atas grafik menunjukkan perbedaan yang nyata dan simbol $\left({ }^{\text {ns }}\right)$ me-nunjukkan tidak adanya per-bedaan yang nyata antar ke-lompok tutupan karang pada alpha $5 \%$, berdasarkan analisis ragam.

Gambar tersebut menunjukkan bahwa hubungan antara jumlah jenis dan kelimpahan ikan karang dengan tutupan karang hidup, meskipun terdapat adanya korelasi positif tetapi tergolong lemah dengan nilai korelasi masing-masing hanya sebesar 0,2098 dan 0,3256. Penambahan 1 $\%$ kondisi terumbu karang hanya meningkatkan jumlah jenis 0,076 satuan, sedangkan untuk kelimpahan hanya meningkat 3,352 ekor/100 $\mathrm{m}^{2}$. Sebaliknya hubungan antara tutupan karang hidup dengan jumlah jenis dan kelimpahan ikan karang berkorelasi negatif dan juga tergolong lemah. Peningkatan tutupan karang mati akan menghilangkan jumlah jenis ikan sebesar 0,01 satuan dan menurunkan kelimpahan sebesar 0,958 ekor $/ 100 \mathrm{~m}^{2}$.

Banyak faktor yang menentukan keragaman dan kelimpahan ikan karang,

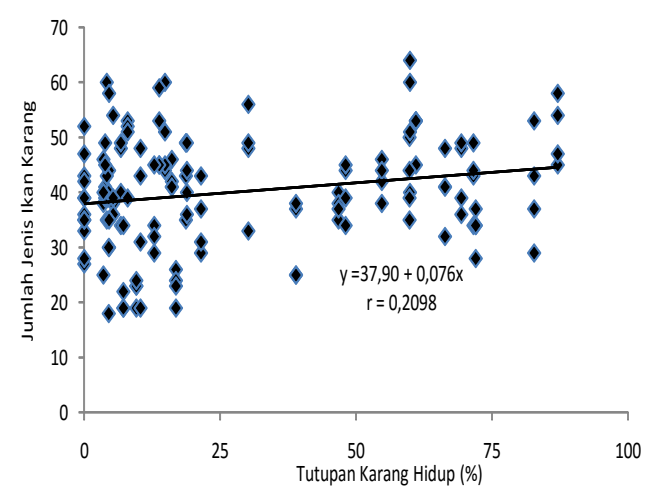

(a) selain tutupan karang hidup atau karang mati. Beberapa faktor tersebut seperti keberadaan atau kedekatan dengan ekosistem sekitarnya seperti kehadiran padang lamun dan mangrove (Rani et al., 2011), tingkat rugositas (Luckhurst and Luckhurst, 1978), dan keberagaman mikrohabitat atau kompleksitas habitat (Carpenter, 1981; Medley et al., 1983; Lewis, 1987). Menurut Luckhurst and Luckhurst (1978), bentuk relief vertikal terumbu karang dan kemiringan substrat berkorelasi dengan kekayaan spesies karang Demikian juga yang dikemukakan oleh Lara and Gonzalez (1998), kompleksitas topografi adalah variabel yang paling penting, namun kedalaman, tutupan karang yang mengerak, dan relief vertikal terumbu karang juga memiliki pengaruh yang signifikan terhadap jenis ikan.

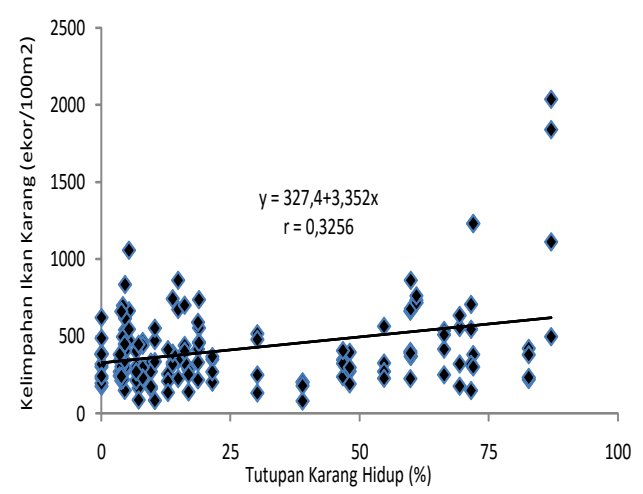

(b) 


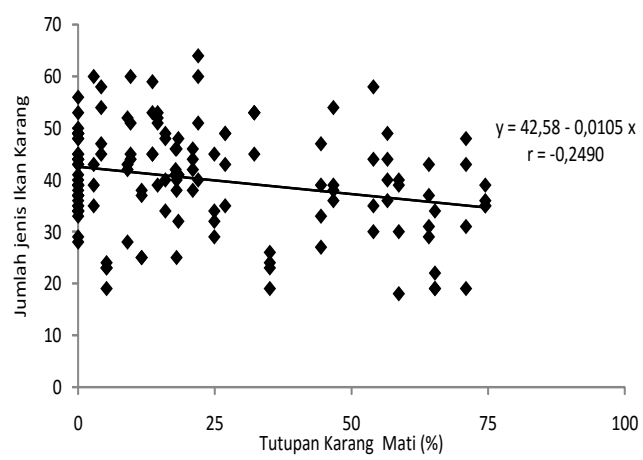

(c)

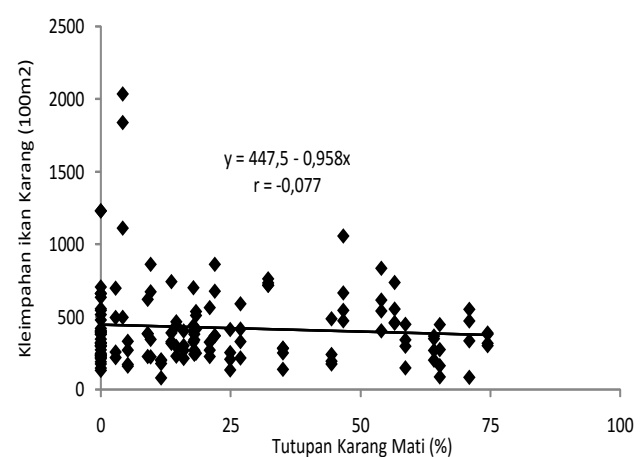

(d)

Gambar 9. Hubungan antara tutupan karang hidup (a) dan karang mati (b) dengan kekayaan jumlah jenis (c) dan kelimpahan (d) dari ikan karang di terumbu karang perairan Pulau Liukangloe, Kab. Bulukumba.

\section{KESIMPULAN}

Dinamika jumlah jenis ikan karang menurut periode pengamatan terpantau di kedalaman 3-5 $\mathrm{m}$ dan memperlihatkan perbedaan yang nyata. Sedangkan di kedalaman 8-10m relatif stabil dan tidak berbeda nyata antar stasiun. Kelimpahan ikan karang pada kedalaman 8-10 m lebih tinggi dibandingkan dengan kelimpahan ikan karang pada kedalaman 3-5 m.

Penutupan karang hidup yang tinggi memberikan perbedaan yang nyata terhadap jumlah jenis ikan karang namun tidak dalam hal kelimpahannya. Terdapat korelasi positif yaitu hubungan antara tutupan karang hidup dengan jumlah jenis dan kelimpahan ikan karang dan sebaliknya berkorelasi negatif pada tutupan karang mati.

\section{UCAPAN TERIMA KASIH}

Penulis menyampaikan terima kasih yang sebesar-besarnya kepada DP2M Dikti yang bersedia dalam membiayai penelitian ini. Terima kasih juga penulis haturkan untuk saudara Aidil Syam, S.Kel. dan Kasman, S. Kel. atas bantuannya dalam pengambilan data di lapangan.

\section{DAFTAR PUSTAKA}

Allen, G.R. 2000. Marine fishes of South East Asia. Kaleidoscope Pront and Prepress Perth. Western Australia. 292p.

Bell, J.D. and R. Galzin. 1984. Influences of live coral cover on coral-reef fish communities. Mar. Ecol. Prog. Ser., 15: 265-274.

Bouchon-Navaroa, Y., C. Bouchon, M. Louis, and P. Legendre. 2005. Biogeographic patterns of coastal fish assemblages in the West Indies. $J$. Exp. Mar. Biol. Ecol., 315: 31-47. https://doi.org/10.1016/j.jembe.2004. 08.028

Carpenter, K.E., R.I. Miclat, W.D. Albaladejo, and V.T. Corpuz. 1981. The influence of substrate structure on the local abundance and diversity of Philippine reef fishes. In: Gomez, E.D. et al. (eds). Prociding of the fourth international coral reef symposium. Marine Science Center, University of The Philippines, Manila, 18-22 May 1981.497-502 pp.

Connell, J.H. 1978. Diversity in Tropical Rain Forests and Coral Reefs. Science, New Series, 199(4335): 1302-1310. 
http://doi.org/10.1126/science.199.43 35.1302

English, S., C. Wilkinson, and V. Baker. 1994. Survey manual for tropical marine resources. Asean. ASEANAustralia Marine Science Project: Living Coastal Resources. Australia. $368 \mathrm{p}$.

Ghiffar, M.A., A. Irham, S.A. Harahap, N. Kurniawaty, dan S. Astuty. 2017. Hubungan kondisi terumbu karang dengan kelimpahan ikan karang target di perairan Pulau Tinabo Besar, Taman Nasional Taka Bonerate, Sulawesi Selatan. Spermonde, 2(3): 17-24.

Gratwicke, B. 2004. Factors affecting fish distribution in coastal habitats of the British Virgin Islands. Thesis. Faculty of Biological Sciences, Oxford University in partial fullfilment of the requirements for the degree of Doctor of Philosophy. Linacre College. 308p.

Hukom, F.D. dan A. Syahailatua. 2010. Pemanfaatan dan pengembangan potensi sumberdaya ikan karang di perairan pulau ambon dan sekitarnya. Prosiding seminar tentang oseanologi dan ilmu lingkungan laut dalam rangka penghargaan kepada Prof. Dr. Aprilani Soegiarto, M.Sc. APU. Pusat Penelitian dan Pengembangan Oseanologi, Jakarta, 7 Oktober 2010. Hlm.: 233-243.

Kuiter, R.H. and T. Tonozuka. 2001. Pictorial guide to Indonesian Reef Fishes. Part1, 2 and 3. Zoo Netics, Seaford Victoria, Australia. 893 pp.

Lara, E.N. and E.A. Gonzalez. 1998. The relationship between reef fish community structure and environmental variables in the southern Mexican Caribbean. J. Fish. Biol., 53(sA): 209-221.

https://doi.org/10.1111/j.10958649.1998.tb01028.x

Lewis, J.B. 1987. Measurements of groundwater seepage flux onto a coral reef: spatial and temporal variations. Limnol. Oceanogr., 32(5): 11651169.

https://doi.org/10.4319/lo.1987.32.5.1 165

Luckhurst, B. and K. Luckhurst. 1978. Analysis of the influence of substrate variables on coral reef communities. Marine Biology, 49(4): 317-323. http://doi.org/10.1007/BF00455026

McManus, J.W., R.I. Miclat, and V.P. Palaganas. 1981. Coral and fish community structure of Sombrero Island, Batangas, Philippines. Proc. $4^{\text {th }}$ Int. Coral Reef Symp., (2):271280. Manila:18-22 May 1981.

Medley, P.A., G. Gaudian, and S. Wells. 1983. Coral reef fisheries stock assessment. J. Fish. Biol., 3: 242-285.

Nirwan, M. Syahdan, dan D. Salim. 2017. Studi kerusakan ekosistem terumbu karang di kawasan wisata bahari Pulau Liukang Loe Kabupaten Bulukumba Provinsi Sulawesi Selatan. Marine Coastal and Small Islands Journal, 1(1): 11-22.

Pratchett, M.S., S.K. Wilson, M.I. Berumen, and M.I. McCormick. 2004. Sublethal effects of coral bleaching on an obligate coral feeding butterflyfish. Coral Reefs, 23: 352-356. https://doi. org/10.1007/s00338-004-0394-x

Rani, C., A.I. Burhanuddin, dan A.A. Attjo. 2011. Sebaran dan keragaman ikan karang di Pulau Barranglompo; Kaitannya dengan kondisi dan kompleksitas habitat. Dalam Isnansetyo, A. et al. (eds.). Prosiding Seminar Nasional Tahunan VII, Hasil Penelitian Perikanan dan Kelautan Tahun 2011 Jilid II: Manajemen Sumberdaya Perikanan. Jurusan Perikanan dan Kelautan, Fakultas Pertanian, Universitas Gadjah Mada, Yogyakarta, Tanggal 16 Juli 2011. KL01:1-15.

Robertson, D.R. and S.D. Gaines. 1986. Interference competition structures 
habitat use in a local assemblage of coral reef surgeonfishes. Ecology, 67: 1372-1383. https://striapps.si.edu/ docs/publications/pdfs/ross_33.pdf

Roberts, C.M. and R.F. Ormond. 1987. Habitat complexity and coral reef diversity and abundance on Red Sea fringing reefs. Mar. Ecol. Prog. Ser., 41: 1-8. http://www.ejmanager.com/ mnstemps/3/3-1430576594.pdf

Sano, M., M. Shimizu, and Y. Nose. 1984. Changes in structure of coral reef fish communities by destruction of hermatypic corals: observational and experimental views. Pac. Sci., 38: 5179. https://core.ac.uk/download/pdf/ 5093561.pdf

Setiawan, F., S. Tasidjawa, E. Wantah, dan H. Johanis. 2016. Biodiversitas ikan karang di daerah perlindungan laut Kabupaten Minahasa Utara, Sulawesi
Utara. J. Ilmu dan Teknologi Kelautan Tropis, 8(1): 57-71. https://doi.org/10.29244/jitkt.v8i1.12 496

Talbot, F.H., B.C. Russell, and G.R.V. Anderson. 1978. Coral Reef Fish Communities: Unstable, HighDiversity Systems? Ecological Monograph, 48(4): 425-440. https://www.jstor.org/stable/2937241 Wilson, S.K., N.A.J. Graham, M.S. Pratchett, G.P. Jones, and N.V.C. Polunin. 2006. Multiple disturbances and the global degradation of coral reefs: are reef fishes at risk or resilient? Global Change Biology, 12(11): 2220-2234. https://doi.org/10.1111/j.13652486.2006.01252.x

Received : 27 March 2019

Reviewed : 12 April 2019

Accepted :05 September 2019 